\title{
PERCEPTIONS
}

\author{
Volume 4, Number 2
}

Spring 2018

\section{WITHOUT BOUNDS}

\section{TUHSSA Temple Undergraduate History and Social Sciences Association}

(C) 2018 Temple University Undergraduate History and Social Sciences Association, all rights reserved

ISSN: 2639-6750

Cover photo: "Away from the Sunset" by Boris Afremov 


\section{Letter from the Editor}

\section{Dear Reader:}

In this, our newest issue of Perceptions, we are honored to share some of the best undergraduate work being done at Temple University. Perceptions is proud to continue serving as Temple's first student-run undergraduate research journal--as a platform for exhibiting the finest undergraduate research in history and the social sciences.

The selected works that we have assembled in this issue coincides with the concept of knowledge and progress being unrestricted by any type of boundary, physical or imagined. Our title for this issue, "Without Bounds," demonstrates that principle. Despite numerous accounts of adversity and strife, human progress is motivated by the hope of improvement and creating a fair and just society for everyone. From the small local problems to those affecting communities around the world, it is incredible to see what humankind is capable of accomplishing. As civil rights activist César Chávez said: "We cannot seek achievement for ourselves and forget about progress and prosperity for our community. Our ambitions must be broad enough to include the aspirations and needs of others, for their sakes and for our own." The opportunities for achievement are essentially limitless and will continue to persist into the future and beyond.

Looking back, this is the fourth issue of Perceptions that I have contributed to, and I cannot help but be proud of the incredible journey this journal had went through. From being the brainchild of an ambitious undergraduate student in 2009, it blossomed into TUHSSA's greatest ever achievement yet. I am grateful for the work that my predecessors and previous TUHSSA members accomplished in making this possible. This semester we received a new record number of submissions and we hope to continue to receive more in coming semesters. Once again, we would like to thank Annie Johnson for setting up Perceptions on Open Journal Systems (OJS) and the Temple University Libraries for hosting this journal. Without them, Perceptions would not be the way it is now.

Sincerely,

Christopher Chau

Editor-in-Chief, Perceptions

President of TUHSSA, Spring 2018 


\section{Inside Vol. 4 No. 2}

ISIS and the "War Makes States Path"

Samantha Anthony, Sophomore, German and Global Studies

The Most Homophobic Place on Earth? A Look into the Anti-Homosexuality Culture of Jamaica

Effi Booth, Junior, Social Studies/Secondary Education

The Illusion of Progress: Evaluating U.N. Women's Rights Instruments

Christina Borst, Sophomore, Political Science and Strategic Communication

Exhibiting an Unapologetic Fascist: Mario Sironi

Fiona Fackler, Senior, Art History

“Machine Town": Panethnic Asian American Identity in Philadelphia Politics

Ronald Raju Joseph, Senior, Political Science

Road to the Civil War: The Missouri Compromise

Julius Nathan Fortaleza Klinger, Junior, History and Secondary Education

Building Girls Capacity in Philadelphia: Meaningful Access to Participatory Action Research and Platforms of Feminist Standpoints

Micaela Robalino, Senior, Political Science and Gender, Sexuality, Women's Studies

How Did Geography Affect the Haitian Revolution?

Jennifer Romine, Junior, History and Spanish

Foreign Aid and Development in the Democratic Republic of the Congo: An Analysis of International Barriers to Development

Anna N. Smith, Senior, Global Studies

Badly Equipped, Under-financed, Technologically Backward but Splendidly Uniformed: A Brief View into Austria- Hungary's Efforts in the Eastern Front and the Battle of Galicia Jack Sweeney, Sophomore, History 


\title{
Editorial Team
}

\section{Editor-in-Chief}

\author{
Christopher Chau \\ Junior, History \& Political Science Major, French Minor
}

\section{Executive Editors}

Sabrina Wallace

Junior, History Major, Political Science Minor

Armon Fouladi

Senior, Actuarial Science Major, History \& International Business Minor

Ronald Joseph

Senior, Political Science Major

\author{
Associate Editors \\ Benjamin Slesinger \\ Junior, Criminal Justice Major, Religion Minor \\ Ellen Taraskiewicz \\ Junior, History Major, Jewish Studies Minor
}

\section{Assistant Editors}

Kyle Baskin

Sophomore, English Major, History Minor

Selena Baugh

Sophomore, Sociology and Africology and African American Studies Major, Spanish Minor

Anna Breece

Senior, Political Science Major, Global Studies (Economy Track) Minor

Alessandra Restifo

Sophomore, Political Science and Global Studies Major 